\title{
PENGETAHUAN DAN KETERAMPILAN BIDAN UNTUK SKRINING KANKER SERVIKS DENGAN METODE INSPEKSI VISUAL ASAM ASETAT (IVA) DI KALIMANTAN BARAT
}

\author{
Mardiana $^{1}$, Djaswadi Dasuki ${ }^{2}$, Heru Pradjatmo²
}

\begin{abstract}
Background: Globally it is estimated that every two minutes a woman dies of cervical cancer and 500,000 women are diagnosed to have cervical cancer each year. In Indonesia, the incidence of cervical cancer is by 12.6 per 100,000 women with a mortality rate of 7 per 100,000 . Screening method can reduce the incidence of cervical cancer if done cumulatively in 2012, the coverage of screening with a VIA method in Indonesia was $1.57 \%$, whereas screening coverage with IVA in West Kalimantan Province was $1.06 \%$

Objective: To assess midwives' knowledge and skills of screening practices with a VIA method in health centers Method: This was an observational study with a cross-sectional study, using quantitative and qualitative approaches. The study was conducted in health centers in the province of West Kalimantan. This study was conducted in September to October 2014. The subjects of research were midwives who served in health centers doing a VIA examination in West Kalimantan who met inclusion and exclusion criteria. The total sample of this study was 42 taken with purposive sampling. The variables of this study were the dependent variable, ie, the practice of screening skills with a VIA method, the independent variable, ie, knowledge, and the extraneous variables, ie, age, education, and years of service. Analysis of the data included univariable, bivariable, multivariable, and qualitative. The quantitative data analysis used the chi-square and logistic regression with a significance level of $\mathrm{p}<0.05$ and an OR value with confidence interval $(\mathrm{Cl})$ of $95 \%$.

Result \& Discussion: The mean value of midwives' knowledge was 26.0 from assessment scores of 0-30. A mean score of screening practice skills was 94.4 from 38-114. Of clinical assessment scores skill practice of competent midwives with good knowledge was higher than bad knowledge (OR=6,98 Cl 95\% 1,21-40,33). After controlling education and years of service variables, good knowledge influenced screening clinical practice by $33 \%$.

Conclusion: Most of the midwives in West Kalimantan had good knowledge and skills to perform cervical cancer screening with a VIA method.
\end{abstract}

Keywords: Knowledge, screening practice skills, VIA methods

\begin{abstract}
ABSTRAK
Latar Belakang: Di seluruh dunia diperkirakan setiap dua menit seorang wanita meninggal karena kanker servik dan sekitar 500.000 wanita di diagnosis kanker seviks setiap tahun. Di Indonesia insiden kanker serviks sebesar 12,6 per 100.000 perempuan dengan angka kematian sebesar 7 per 100.000. Metode skrining dapat menurunkan kejadian kanker serviks jika dilakukan secara kumulatif. Pada tahun 2012 cakupan skrining dengan metode IVA di Indonesia sebesar 1,57\%, sedangkan cakupan skrining dengan metode IVA Propinsi Kalimantan Barat sebesar 1,06\%.

Tujuan: Menilai pengetahuan dan keterampilan praktek skrining bidan dengan metode IVA di puskesmas

Metode: Jenis penelitian observasional dengan rancangan cross-sectional study, menggunakan pendekatan kuantitatif dan kualitatif. Penelitian dilakukan di puskesmas di Provinsi Kalimantan Barat. Penelitian ini dilaksanakan bulan September sampai dengan Oktober 2014. Subjek penelitian bidan yang melayani pemeriksaan IVA di puskesmas di Provinsi Kalimantan Barat yang memenuhi kriteria inklusi dan eksklusi. Total sampel penelitian ini 42 sampel dengan pengambilan sampel purposive sampling. Variabel penelitian ini yaitu: variabel terikat adalah keterampilan praktek skrining metode IVA, variabel bebas: pengetahuan, dan variabel luar: usia, pendidikan, dan lama bekerja.
\end{abstract}

Dinas Kesehatan Provinsi Kalimantan Barat

2. Bagian Obstetri dan Ginekologi Fakultas Kedokteran Universitas Gadjah Mada Yogyakarta 
Analisis data meliputi: univariabel, bivariabel, multivariabel, dan kualitatif. Untuk analisis data kuantitatif menggunakan metode chi square dan logistic regresi dengan tingkat kemaknaan $\mathrm{p}<0,05$ dan nilai OR dengan Confidence Interval (Cl) 95\%.

Hasil \& Pembahasan: Nilai mean pengetahuan bidan sebesar 26,0 dari skor penilaian 0-30. Keterampilan praktik dengan nilai mean 94,4 dari skor 38-114. Keterampilan praktik klinik yang kompeten lebih tinggi pada bidan berpengetahuan baik daripada bidan berpengetahuan kurang (OR=6,98 Cl 95\% 1,21-40,33). Pengetahuan baik setelah dikontrol variabel pendidikan dan lama bekerja berpengaruh terhadap keterampilan praktik skrining sebesar 33\%.

Kesimpulan: Sebagian besar bidan di Kalimantan Barat memiliki pengetahuan baik dan keterampilan yang kompeten untuk skrining kanker serviks dengan metode IVA.

Kata Kunci: Pengetahuan, keterampilan praktek skrining, metode IVA

\section{PENDAHULUAN}

Kanker serviks merupakan penyebab kematian tertinggi kedua di dunia pada wanita setelah kanker payudara. Diperkirakan di dunia setiap dua menit wanita meninggal karena kanker servik dan \pm 500.000 wanita didiagnosis kanker seviks setiap tahunnya. ${ }^{1}$ Di Indonesia penderita kanker serviks jumlahnya terus meningkat. Berdasarkan data Kementerian Kesehatan Republik Indonesia (Kemenkes RI) saat ini terdapat sekitar 100 kasus per 100.000 penduduk atau 200.000 kasus setiap tahunnya. Selain itu, lebih dari $70 \%$ kasus di rumah sakit sudah dalam keadaan stadium lanjut. $^{2}$

Pemeriksaan sederhana, efektif dalam biaya pemeriksaan merupakan pendekatan skrining untuk pencegahan kanker serviks di negara sedang berkembanga dan sumber daya yang rendah dengan skrining visual dengan asam asetat (IVA). ${ }^{3}$ Di negara berkembang diperkirakan wanita yang dilakukan skrining hanya mencapai $5 \%$ dalam jangka waktu 5 tahun. Sedangkan di negara maju minimal 1 kali sebanyak 70\%. Menurut World Health Organization (WHO) seharusnya skrining dapat mencapai $80 \% .{ }^{4}$ Berdasarkan laporan tahunan Dinas Kesehatan Propinsi Kalimantan Barat tahun 2010-2012 jumlah yang diperiksa IVA hanya 0,90\% dari target yang ditetapkan Kementerian Kesehatan yaitu 80\%. Salah satu upaya untuk meningkatkan program skrining dengan mobilisasi sumber daya manusia dengan melatih bidan dan dokter umum di puskesmas untuk talaksana skrining dengan metode IVA. Dua puluh satu persen puskesmas, $19 \%$ dokter umum di puskesmas dan $3 \%$ bidan yang telah dilatih untuk melaksanakan skrining dengan metode IVA. Tujuan penelitian ini adalah menilai pengetahuan dan keterampilan praktik bidan untuk skrining kanker serviks dengan metode IVA di puskesmas di Kalimantan Barat.

\section{METODE PENELITIAN}

Penelitian ini merupakan penelitian observasional dengan rancangan cross-sectional, menggunakan pendekatan kuantitatif dan kualitatif. ${ }^{(5)}$ Penelitian ini menilai pengetahuan dan ketrampilan praktek bidan untuk skrining kanker serviks dengan metode IVA di puskesmas di Propinsi Kalimantan Barat yang sudah dilatih skrining dengan metode IVA dari tahun 2010 sampai tahun 2013.

Populasi dan subjek penelitian adalah seluruh bidan yang sudah dilatih di puskesmas yang melayani pemeriksaan IVA di 5 Kabupaten/Kota di Kalimantan Barat yang memenuhi kriteria inklusi: bidan yang sudah mendapatkan pelatihan dan mempunyai sertifikat pelatihan. Kriteria eksklusi: bidan yang tidak mempunyai sertifikat pelatihan. Bidan yang melayani skrining IVA tetapi sedang melanjutkan pendidikan, mutasi kerja.

Penelitian ini menggunakan total sampling, dengan sampel awal 62 bidan. Sampel yang masuk 
kriteria inklusi berjumlah 42 bidan, dengan rincian sebagai berikut: Kota Pontianak 18 bidan, Kabupaten Pontianak 6 bidan, Kota Singkawang 6 bidan, KabupatenSintang 6 bidan, dan Kabupaten Kubu Raya 6 bidan. Sampel diambil berdasarkan kelompok wilayah atau Kab/Kota dengan jumlah Bidan yang dilatih lebih dari 5 orang. Pengambilan sampel dilakukan dengan purposive sampling berdasarkan kelompok wilayah atau Kabupaten/Kota. Adapun alur pengambilan sampel mengacu pada Strobe Guidelines. ${ }^{6,7}$

Variabel penelitian ini: 1) variabel terikat adalah: keterampilan praktek skrining; 2 ) variabel bebas adalah: pengetahuan; dan 3) variabel luar meliputi: umur, pendidikan, lama bekerja. Instrumen dalam penelitian ini menggunakan wawancara dan observasi dengan panduan kuesioner maupun lembar observasi, dan pengisian kuisioner. Teknik analisis yang digunakan adalah: analisis univariabel, bivariabel, multivariabel dan kualitatif. Uji statistik chi square $\left(X^{2}\right)$ dan regresi logistik dengan tingkat kemaknaan sebesar $p$ $<0,05$ dan Confidence Interval (CI) 95\%.

\section{HASIL PENELITIAN DAN PEMBAHASAN}

1. Gambaran Karakteristik Bidan Berdasarkan Usia, Pendidikan, Lama Bekerja, Keterampilan Praktik Skrining dan Pengetahuan

Pada Tabel 1 disajikan beberapa variabel karakteristik gambaran responden meliputi: usia, tingkat pendidikan, lama bekerja, keterampilan praktek skrining, dan pengetahuan bidan.

Tabel 1. Karakteristik bidan berdasarkan usia, pendidikan, lama bekerja, keterampilan praktik skrining dan pengetahuan

\begin{tabular}{|c|c|c|}
\hline Variabel & $\mathrm{n}$ & $\%$ \\
\hline \multicolumn{3}{|l|}{ Usia } \\
\hline = 35 tahun & 26 & 61,9 \\
\hline$<35$ tahun & 16 & 38,1 \\
\hline \multicolumn{3}{|l|}{ Pendidikan } \\
\hline Tinggi & 31 & 73,81 \\
\hline Rendah & 11 & 26,19 \\
\hline \multicolumn{3}{|l|}{ Lama bekerja } \\
\hline$=10$ tahun & 21 & 50,0 \\
\hline$<10$ tahun & 21 & 50,0 \\
\hline \multicolumn{3}{|c|}{ Keterampilan praktik skrining } \\
\hline Kompeten & 28 & 66,7 \\
\hline Tidak kompeten & 14 & 33,3 \\
\hline \multicolumn{3}{|l|}{ Pengetahuan } \\
\hline Baik & 26 & 61,9 \\
\hline Kurang & 16 & 38,1 \\
\hline
\end{tabular}

Dari gambaran karakteristik bidan pada Tabel 1, maka dapat disimpulkan bahwa lebih dari setengah bidan pada penelitian ini mempunyai usia $>35$ tahun. Sedangkan tiga perempat bidan dengan pendidikan tinggi yaitu > D3, dan seperempat bidan pendidikan rendah D1. Untuk lama bekerja jumlah bidan yang lebih atau sama dengan 10 tahun dengan yang kurang dari 10 tahun jumlahnya sama besar.

Berdasarkan hasil observasi langsung keterampilan praktik skrining ditemukan dua pertiga bidan yang kompeten dalam melakukan praktek skrining dengan metode IVA, sepertiganya tidak kompeten. 
Dari nilai kuesioner didapatkan pengetahuan bidan yang baik jumlahnya lebih dari setengah dan kurang dari setengah jumlah bidan yang memiliki pengetahuan tidak baik.

Tabel 2 menunjukkan bahwa skor rerata pengetahuan bidan sebesar $26,0 \pm 1,9$. Untuk skor

\section{Hubungan Antara Pengetahuan Bidan dengan Keterampilan Praktik Skrining}

rerata keterampilan praktik skrining bidan yang diobservasi langsung sebesar 94,4 $\pm 15,1$.

Tabel 2. Rerata skor pengetahuan dan keterampilan praktik skrining bidan dengan metode IVA

\begin{tabular}{lcc}
\hline Variabel & Mean \pm SD & Min-max \\
\hline Pengetahuan & $26,0 \pm 1,9$ & $22-30$ \\
Keterampilan & $94,4 \pm 15,1$ & $74-114$ \\
\hline
\end{tabular}

Tabel 3. Uji chi square pengetahuan bidan dengan keterampilan praktik skrining

\begin{tabular}{ccccccccc}
\hline \multicolumn{8}{c}{ Keterampilan praktik skrining } \\
Variabel & \multicolumn{1}{c}{ Kompeten Tidak kompeten } & $\mathrm{c}^{2}$ & $\boldsymbol{P}$ & $\mathrm{RP}$ & $\mathbf{9 5 \%} \mathrm{Cl}$ \\
& $\mathbf{n}$ & $\%$ & $\mathbf{n}$ & $\%$ & & & & \\
\hline Pengetahuan & & & & & & & & \\
Baik & 21 & 80,8 & 5 & 19,2 & 6,11 & 0,013 & 1,85 & $1,03-3,32$ \\
Kurang & 7 & 43,7 & 9 & 56,3 & & & & \\
\hline
\end{tabular}

Ket: $\mathrm{n}=$ Jumlah bidan $\quad \mathrm{c}^{2}=$ Chi-Square $\quad p=p$-value $\quad \mathrm{RP}=$ Rasio Prevalensi $95 \%$

$\mathrm{Cl}=$ Confidence Interval $95 \% *$ Signifikansi $(p<0,05)$

Tabel 3 menunjukkan bahwa ada hubungan yang bermakna antara pengetahuan dengan keterampilan praktik skrining menggunakan metode IVA, baik secara statistik dan praktis dengan nilai $p<0,05$ dan RP 1,85. Artinya bidan yang pengetahuannya baik berpeluang hampir dua kali lebih besar untuk melakukan keterampilan praktik skrining yang kompeten dibandingkan bidan dengan pengetahuan kurang. Nilai mean pengetahuan bidan sebesar 26,0, dikatakan pengetahuan baik jika skor < 26, pengetahuan kurang apabila skor $<26$. Keterampilan praktik skrining kompeten jika skor $>76$ dari komponen standar skrining IVA dan dikatakan tidak kompeten jika skor $<76$.

\section{Hubungan Antara Usia, Pendidikan, dan Lama Bekerja Bidan dengan Keterampilan Praktik Skrining}

Pada Tabel 4 disajikan hubungan antara variabel luar (usia, pendidikan dan lama bekerja) dengan variabel terikat (keterampilan praktik skrining). 
Tabel 4. Uji chi square usia, pendidikan, dan lama bekerja bidan dengan keterampilan praktik skrining

\begin{tabular}{|c|c|c|c|c|c|c|c|c|}
\hline \multirow{3}{*}{ Variabel } & \multicolumn{4}{|c|}{ Keterampilan praktik skrining } & \multirow{3}{*}{$x^{2}$} & \multirow{3}{*}{$P$} & \multirow{3}{*}{ RP } & \multirow{3}{*}{$95 \% \mathrm{Cl}$} \\
\hline & \multicolumn{2}{|c|}{ Kompeten } & \multicolumn{2}{|c|}{ Tidak kompeten } & & & & \\
\hline & $\mathbf{n}$ & $\%$ & n & $\%$ & & & & \\
\hline \multicolumn{9}{|l|}{ Usia } \\
\hline$\geq 35$ tahun & 20 & 76,9 & 6 & 23,1 & 3,23 & 0,07 & 1,54 & $0,90-2,62$ \\
\hline$<35$ tahun & 8 & 50,0 & 8 & 50,0 & & & & \\
\hline \multicolumn{9}{|l|}{ Pendidikan } \\
\hline Tinggi & 24 & 7,4 & 7 & 22,6 & 6,16 & 0,01 & 2,13 & $1,16-3,89$ \\
\hline Rendah & 4 & 36,4 & 7 & 63,6 & & & & \\
\hline \multicolumn{9}{|l|}{ Lama bekerja } \\
\hline$\geq 10$ tahun & 18 & 85,7 & 3 & 14,3 & 6,86 & 0,01 & 1,80 & $1,11-2,91$ \\
\hline$<10$ tahun & 10 & 47,6 & 11 & 52,4 & & & & \\
\hline
\end{tabular}

Keterangan: $\mathrm{n}=$ Jumlah Bidan $\mathrm{c}^{2}=$ Chi-Square $p=p$-value $\mathrm{RP}=$ Rasio Prevalensi $95 \% \mathrm{Cl}=$ Confidence Interval $95 \% *$ Signifikansi $(p<0,05)$

Pada penelitian ini secara statistik tidak terdapat hubungan yang bermakna antara usia dengan keterampilan praktik skrining dengan nilai $p>0,05$, tetapi secara praktis terdapat hubungan yang bermakna dengan nilai RP 1,54, Artinya bidan yang berusia $>35$ tahun berpeluang satu setengah kali lebih besar untuk melakukan keterampilan praktik skrining yang kompeten dibandingkan bidan yang berusia $<35$ tahun.

Ada hubungan yang bermakna secara statistik maupun praktis antara pendidikan bidan dengan keterampilan praktik skrining dengan nilai $p<0,05$ dan RP 2,13. Hal ini berarti bidan berpendidikan tinggi berpeluang dua kali lebih besar untuk melakukan keterampilan praktik skrining yang kompeten dibandingkan bidan dengan pendidikan rendah.
Secara statistik dan praktis ada hubungan yang bermakna antara lama bekerja bidan dengan keterampilan praktik skrining dengan nilai $p<0,05$ dan RP 1,80. Artinya bidan dengan lama bekerja $>10$ tahun berpeluang hampir dua kali lebih besar untuk melakukan keterampilan praktik skrining yang kompeten dibandingkan bidan dengan lama bekerja $<10$ tahun.

\section{Hubungan Antara Usia, Pendidikan, dan Lama Bekerja Bidan dengan Pengetahuan Bidan}

Pada Tabel 5 berikut disajikan hubungan variabel luar (usia, pendidikan, dan lama bekerja bidan) dengan variabel bebas (pengetahuan bidan). 
Tabel 5. Uji chi square usia, pendidikan, dan lama bekerja bidan dengan pengetahuan bidan

\begin{tabular}{|c|c|c|c|c|c|c|c|c|}
\hline \multirow{3}{*}{ Variabel } & \multicolumn{4}{|c|}{ Pengetahuan } & \multirow{3}{*}{$c^{2}$} & \multirow{3}{*}{$\mathbf{P}$} & \multirow{3}{*}{ RP } & \multirow{3}{*}{$\mathrm{Cl}$} \\
\hline & \multicolumn{2}{|c|}{ Baik } & \multicolumn{2}{|c|}{ Kurang } & & & & \\
\hline & $\mathbf{n}$ & $\%$ & $n$ & $\%$ & & & & \\
\hline \multicolumn{9}{|l|}{ Usia } \\
\hline$=35$ tahun & 16 & 61,5 & 10 & 38,5 & 0,00 & 0,95 & 0,98 & $0,60-1,60$ \\
\hline$<35$ tahun & 10 & 62,5 & 6 & 37,5 & & & & \\
\hline \multicolumn{9}{|l|}{ Pendidikan } \\
\hline Tinggi & 20 & 64,52 & 11 & 35,48 & 0,34 & 0,56 & 1,18 & $0,65-2,15$ \\
\hline Rendah & 6 & 54,55 & 5 & 45,45 & & & & \\
\hline \multicolumn{9}{|l|}{ Lama bekerja } \\
\hline$=10$ tahun & 14 & 66,7 & 7 & 33,3 & 0,40 & 0,52 & 1,16 & $0,72-1,88$ \\
\hline$<10$ tahun & 12 & 57,1 & 9 & 42,9 & & & & \\
\hline
\end{tabular}

Keterangan: $\mathrm{n}=$ Jumlah Bidan $\quad \mathrm{c}^{2}=$ Chi-Square $p=p$-value RP $=$ Rasio Prevalensi $95 \% \mathrm{Cl}=$ Confidence Interval $95 \% *=$ Signifikansi $(p<0,05)$

Hasil analisis pada Tabel 5 memperlihatkan bahwa tidak terdapat hubungan yang bermakna antara usia bidan, pendidikan dan lama bekerja dengan pengetahuan bidan baik secara statistik maupun praktis. Hal ini berarti bahwa upaya peningkatan pengetahuan tidak dibatasi usia, pendidikan ataupun lama bekerja.

5. Hubungan Antara Pengetahuan dengan Keterampilan Praktik Skrining dalam Menggunakan Metode IVA Menyertakan Variabel Usia, Pendidikan, dan Lama Bekerja

Pada Tabel 6 dilakukan analisis bersama-sama antara variabel bebas dengan variabel terikat menggunakan uji regresi logistik (logistic regression) dengan tingkat kemaknaan $p<0,05$ dan confidence interval (CI) 95\%. Tujuannya untuk menentukan faktor mana yang paling berhubungan antara pengetahuan, pendidikan, dan lama bekerja bidan dengan keterampilan praktik skrining dalam menggunakan metode IVA di Kalimantan Barat. Nilai koefisien determinasi $\left(\mathrm{R}^{2}\right)$ menunjukkan persentase besaran pengaruh terhadap variabel terikat. Semakin baik nilai $\mathrm{R}^{2}$ semakin baik variabel bebas memprediksi variabel terikat. 
Tabel 6. Model hubungan pengetahuan, usia, pendidikan, dan lama bekerja bidan terhadap keterampilan praktik skrining

\begin{tabular}{|c|c|c|c|c|}
\hline Variabel & $\begin{array}{c}\text { Model } 1 \\
\text { OR } \\
\text { (CI 95\%) }\end{array}$ & $\begin{array}{c}\text { Model } 2 \\
\text { OR } \\
\text { (CI 95\%) }\end{array}$ & $\begin{array}{c}\text { Model } 2 \\
\text { OR } \\
\text { (CI 95\%) }\end{array}$ & $\begin{array}{c}\text { Model } 4 \\
\text { OR } \\
\text { (CI 95\%) }\end{array}$ \\
\hline \multicolumn{5}{|l|}{ Pengetahuan } \\
\hline Baik & 5,4 & 6,19 & 6,30 & 6,98 \\
\hline Tidak baik & $1,34-21,63$ & $1,31-29,16$ & $1,30-30,50$ & $1,20-40,33$ \\
\hline \multicolumn{5}{|l|}{ Pendidikan } \\
\hline Tinggi & & 6,96 & & 7,23 \\
\hline Rendah & & $1,31-36,91$ & & $1,01-51,85$ \\
\hline \multicolumn{5}{|l|}{ Lama bekerja } \\
\hline$\geq 10$ tahun & & & 7,61 & 6,76 \\
\hline$<10$ tahun & & & $1,46-39,70$ & $1,22-37,27$ \\
\hline $\mathrm{N}$ & 42 & 42 & 42 & 42 \\
\hline Deviance & 47,38 & 41,62 & 40,42 & 36,08 \\
\hline $\mathrm{R}^{2}$ & 0,11 & 0,22 & 0,24 & 0,32 \\
\hline
\end{tabular}

Berdasarkan hasil permodelan Tabel 6, maka dapat disimpulkan model yang cukup baik untuk dapat menjelaskan faktor-faktor penting yang berhubungan secara statistik dan praktis dengan keterampilan praktik skrining dengan metode IVA adalah model 4 . Hal ini dengan mempertimbangkan nilai $\mathrm{R}^{2}$, deviance, OR serta Convidence Interval ( $\left.\mathrm{Cl}\right)$. Pada model 4 tersebut nilai $R^{2}$ dan OR cenderung meningkat dibandingkan model 1, 2 dan 3. Sementara nilai deviance model 4 semakin kecil dibandingkan model 1,2 dan model 3 . dengan mempertimbangkan nilai $R^{2}$ dan deviance.

\section{Hasil wawancara mendalam}

a. Gambaran pengetahuan tentang skrining kanker serviks dengan metode IVA

Persentase bidan yang memiliki pengetahuan baik pada penelitian ini sebesar $61,9 \%$ dan $38,1 \%$ yang kurang. Hampir semua responden menyatakan bahwa mereka belum pernah mendapatkan informasi pengetahuan tentang kanker serviks dan skrining kanker serviks dengan metode IVA di tempat lain. Kebanyakan mereka memperoleh informasi dari pelatihan yang diadakan oleh Dinas Kesehatan Provinsi Kalimantan Barat.

Dari hasil wawancara mendalam dapat disimpulkan bahwa selama ini hanya mendapat informasi dari pelatihan yang diperoleh dari Dinas Kesehatan. Perlu adanya pemberian kesempatan bagi mereka untuk memperoleh informasi tentang pengetahuan skrining kanker serviks dengan metode IVA dari luar. Misalnya dengan mengirim mereka ke seminar maupun pertemuan tentang hal tersebut agar mereka dapat saling bertukar ilmu dan pendapat dengan peserta dari daerah lain untuk menambah wawasan mereka.

b. Gambaran keterampilan praktik klinik bidan untuk skrining kanker serviks dengan metode IVA

Persentase bidan yang memiliki keterampilan kompeten pada penelitian ini sebesar $66,67 \%$ dan $33,33 \%$ yang tidak kompeten. Sebagian responden menyatakan bahwa mereka tidak mengalami kesulitan dalam memasang spekulum, menemukan SSK (sambungan skuamo kolumner) dan porsio. 
Dari hasil wawancara mendalam dapat diambil kesimpulan bahwa keterampilan menggunakan spekulum, mencari SSK dan porsio pada sebagian responden masih mengalami kesulitan. Hal ini disebabkan pasien merasa tegang dan kesakitan saat dilakukan pemeriksaan IVA terutama saat pemasangan spekulum. Diperlukan latihan dan pemeriksaan IVA yang rutin agar keterampilan memasang spekulum, mencari SSK dan porsio dapat dilakukan dengan mudah dan kompeten.

c. Saran untuk menambah pengetahuan dan keterampilan tentang skrining kanker serviks dengan metode IVA

Dari beberapa informan mengatakan bahwa hampir semua mengungkapkan perlu adanya penyegaran, pelatihan dan pengobatan IVA gratis oleh Dinas Kesehatan Provinsi Kalimantan Barat.

Dari hasil wawancara mendalam dapat disimpulkan bahwa semua responden mengatakan untuk meningkatkan pengetahuan dan keterampilan skrining IVA perlu selalu diadakan pelatihan serta penyegaran yang rutin dan dibuat program seperti program-program yang telah berjalan di dinas. Disamping itu tenaga bidan yang dilatih tidak hanya terbatas satu orang namun bisa ditambahkan serta selalu dilakukan monitoring dan pengawasan dari Dinas Kesehatan Provinsi agar kompetensi bidan terjaga.

\section{Uraian Pembahasan}

\section{Hubungan Antara Pengetahuan Bidan dengan Keterampilan Praktik Skrining}

Pengetahuan juga merupakan hasil dari mengingat suatu hal, baik kejadian yang pernah dialami secara sengaja atau tidak sengaja dimana hal ini terjadi setelah seseorang melakukan kontak ataupun melakukan suatu pengamatan terhadap suatu objek. ${ }^{8}$ Adapun faktor-faktoryang mempengaruhi pengetahuan seseorang adalah tingkat pendidikan, pekerjaan, umur, minat, pengalaman, kebudayaan, serta informasi yang ada. ${ }^{9}$
Berdasarkan hasil dari penelitian yang telah dilakukan, didapatkan bahwa pengetahuan bidan terhadap metode Inspeksi Visual Asam Asetat sebagian besar responden mempunyai pengetahuan yang baik. Dari 42 responden penelitian nilai ratarata pengetahuan bidan sebesar 26,0 . Hal ini dikarenakan sudah banyaknya informasi dan pelatihan yang didapatkan responden dari instansi terkait. Namun yang masih kurang mereka dapatkan dari informasi dan pelatihan diperoleh dari luar, misalnya informasi dan pelatihan yang diperoleh dari tempat lain. Pendapat ini sesuai dengan hasil wawancara yang dilakukan bahwa hampir seluruh responden hanya memperoleh informasi dari Dinas Kesehatan Provinsi Kalimantan Barat.

Untuk memperoleh akses terhadap informasi yang baik perlu diberikan kemudahan dalam seminar dan pelatihan yang dirancang khusus untuk staf paramedis di semua jenis fasilitas kesehatan. Hal ini diharapkan secara signifikan dapat meningkatkan proporsi bidan dengan pengetahuan yang memadai tentang skrining kanker seviks. ${ }^{10}$

Secara konsep yang dimaksud dengan penguasaan kompetensi yaitu pernyataan yang menunjukkan adanya hubungan yang baik antara kemampuan penguasaan pengetahuan dengan penguasaan keterampilan klinis dalam sistem pelayanan kesehatan. ${ }^{11}$ Rendahnya kemampuan kinerja bidan dan perawat sebagai penyedia layanan kesehatan ibu dalam praktik klinik berhubungan dengan pengetahuan dan keterampilan yang dimiliki oleh perawat dan bidan. ${ }^{12}$

Dari hasil penelitian juga didapatkan pengetahuan dan keterampilan praktik skrining bidan dengan menggunakan metode IVA yang kompeten lebih besar dibandingkan dengan bidan yang mempunyai pengetahuan kurang. Sedangkan menurut hasil wawancara dan tertulis, beberapa responden mengaku bahwa mereka perlu penyegaran, pelatihan dan skrining IVA masal dan gratis oleh Dinas Kesehatan Provinsi Kalimantan Barat. Kepatuhan 
seseorang terhadap standar prosedur dipengaruhi juga oleh pengetahuan dan pendidikan individu tersebut. Semakin tinggi tingkat pengetahuan, semakin mempengaruhi ketaatan terhadap standar prosedur yang berlaku. ${ }^{13}$ Apabila pelatihan IVA dilakukan sesuai standar kompetensi akan dapat meningkatkan pengetahuan, sikap, perilaku dan keterampilan awal, mampu dan mahir atau skill acquisition, skill competency sampai ke tingkat skill proficiency. ${ }^{7}$ Program pelatihan yang efektif akan meningkatkan pengetahuan dan keterampilan bidan. ${ }^{14}$

\section{Hubungan antara usia dengan keterampilan praktik skrining}

Pada penelitian ini secara statistik tidak terdapat hubungan yang bermakna antara usia dengan keterampilan praktik skrining, tetapi secara praktis terdapat hubungan yang bermakna. Bidan yang berusia $>35$ tahun berpeluang satu setengah kali lebih besar untuk melakukan keterampilan praktik skrining yang kompeten dibandingkan bidan yang berusia $<35$ tahun.

Hal ini berbeda dengan pendapat bahwa usia sangat berpengaruh terhadap proses pelaksanaan skrining IVA, khususnya usia 25-35 tahun merupakan usia yang paling produktif dalam melaksanakan tugas/pekerjaan. Usia yang dimaksud adalah kelompok usia petugas kesehatan yang melaksanakan skrining IVA di fasilitas pelayanan. ${ }^{15}$

Pengetahuan lebih baik pada perawat usia muda dan pengetahuan berbeda secara signifikan antara tingkatan perawat. ${ }^{16}$ Semua perawat dapat meningkatkan kualitas keterampilan praktik skrining kanker payudara, dan kanker serviks dengan pap test, jika melakukan praktek skrining secara rutin. ${ }^{17}$

\section{Hubungan antara pendidikan dengan keterampilan praktik skrining}

Pendidikan adalah suatu usaha untuk mengembangkan kepribadian dan kemampuan di dalam dan di luar pekerjaan (baik formal maupun informal). Semakin tinggi pendidikan seseorang maka semakin mudah orang tersebut untuk menerima informasi. ${ }^{18}$

Hasil penelitian juga mengemukakan bahwa pendidikan berhubungan secara statistik dan praktis dengan keterampilan praktik skrining. Bidan berpendidikan tinggi lebih besar dibandingkan bidan berpendidikan rendah dalam hal kompeten keterampilan praktik skrining dengan metode IVA. Pendapat ini sesuai dengan pernyataan bahwa responden yang memiliki tingkat pendidikan lebih tinggi memilih untuk menggunakan alternatif Inspeksi Visual Asam Asetat sebesar 31,3\%. ${ }^{19}$

Namun hasil penelitian tersebut berbeda dengan pendapat bahwa tidak terdapat perbedaan yang bermakna dalam tingkat pendidikan yang menjalani pelatihan dan yang tidak menjalani pelatihan. ${ }^{20}$ Untuk dapat melaksanakan keterampilan petugas dalam pelaksanaan skrining IVA, tingkat pendidikan tidak cukup tetapi harus disertai perubahan kepercayaan, sikap, dan konsep berfikir dari individu. Pendidikan hanya merupakan faktor pendorong untuk melakukan tindakan secara umum dalam praktek skrining IVA. ${ }^{21}$

Perawat dan bidan diharapkan berperan dalam upaya pencegahan dan deteksi dini kanker serviks. Apabila mereka dilatih untuk mengembangkan pengertian dan praktik yang lebih baik tentang skrining kanker serviks selama pendidikan secara aktif, maka akan dapat meningkatkan keterampilan praktik skrining. ${ }^{22}$

\section{Hubungan antara lama bekerja dengan keterampilan praktik skrining}

Semakin lama bekerja petugas, biasanya tingkat keterampilan pekerjaannya akan semakin meningkat. Produktivitas seseorang yang sudah lama bekerja di faslitas pelayanan, artinya dengan bertambahnya lama bekerja, bisa mengalami peningkatan karena lebih banyak pengalaman dan lebih bijaksana dalam menjalankan tugasnya. ${ }^{23}$ 
Berdasarkan hasil penelitian ini secara statistik dan praktis ada hubungan yang bermakna antara lama bekerja bidan dengan keterampilan praktik skrining. Bidan dengan lama bekerja $>10$ tahun berpeluang hampir dua kali lebih besar untuk melakukan keterampilan praktik skrining yang kompeten dibandingkan lama bekerja $<10$ tahun. Jadi lama bekerja dapat meningkatkan keterampilan bidan dalam melakukkan skrining kanker serviks.

Hal ini sejalan dengan penelitian pada mahasiswa kedokteran tingkat akhir, $87 \%$ belum pernah melakukan pap smear, $56 \%$ belum pernah melakukan pemeriksaan spekulum dan hanya $14 \%$ yang terampil untuk menggunakan spekulum. ${ }^{9}$ Pengalaman lama bekerja yang lebih dari 5 tahun praktek skrining menggunakan metode Inspeksi Visual Asam Asetat meningkat sebanyak $40,7 \%{ }^{24}$

Lama bekerja >10 tahun menunjukkan pengalaman dalam pemeriksaan, tingkat kinerja dan kepatuhan terhadap prosedur yang tinggi dibandingkan lama bekerja $<10$ tahun. ${ }^{25}$ Lama bekerja seseorang juga menunjukkan hubungan yang positif terhadap kinerja seseorang. Masa kerja yang lama menunjukkan pengalaman yang lebih baik dibandingkan yang lebih sedikit. ${ }^{26}$

\section{KESIMPULAN DAN SARAN}

Pengetahuan bidan yang baik berpeluang hampir tujuh kali lebih besar untuk melakukan keterampilan praktik skrining yang kompeten dibandingkan bidan dengan pengetahuan kurang. Bidan dengan pendidikan tinggi berpeluang tujuh kali lebih besar untuk melakukan praktik skrining kompeten menggunakan metode IVA dibandingkan bidan dengan pendidikan rendah. Bidan yang mempunyai lama kerja lebih atau sama dengan 10 tahun berpeluang hampir tujuh kali lebih besar untuk melakukan skrining kanker serviks yang kompeten dibandingkan bidan yang lama kerjanya kurang dari 10 tahun. Keterampilan praktik skiring dalam penggunakan spekulum, mencari Sambungan Skuamosa Kolumnar dan porsio pada sebagian bidan ada yang menemukan kesulitan karena beberapa faktor diantaranya pasien gemuk, usia lanjut, saat pemeriksaan pasien tegang dan takut.

Berdasarkan hasil pembahasan dan kesimpulan yang telah dikemukan diatas, dapat diambil beberapa saran sebagai berikut: 1) perlu adanya peningkatan pengetahuan dan keterampilan bidan untuk skrining kanker serviks dengan pelatihan, training dan workshop disertai dukungan biaya serta sistem pengorganisasian pelayanan kinerja yang baik; 2) bidan diharapkan melakukan praktek skrining secara rutin untuk meningkatkan kualitas keterampilan dan integrasi program pada setiap wanita yang datang untuk mendapatkan pelayanan Keluarga Berencana (KB), Infeksi Menular Seksual (IMS) dan program skrining kanker serviks dengan metode IVA; 3) dukungan biaya diharapkan dari pemerintah daerah untuk kegiatan program skrining kanker serviks dengan metode IVA; dan 4) dukungan Dinkes Propinsi Kalimantan Barat untuk mempromosikan program skrining kanker serviks dengan metode IVA.

\section{DAFTAR PUSTAKA}

1. ACCP. Recent Evidence on Cervical Cancer Screening in Low-Resource Settings 2011 [cited 20145 Februari]. Available from: http://www.allianceexca.org/files/ACCP_exca_screening_2011.pdf

2. Kemenkes RI. Statistik Penderita Kanker di Indonesia Jakarta: Kementerian Kesehatan RI; 2013.

3. Sankaranarayanan R, Nessa A, Esmy PO, Dangou J$M$. Visual inspection methods for cervical cancer prevention. Best practice \& research Clinical obstetrics \& gynaecology. 2012;26(2):221-32.

4. Carr KC, Sellors JW. Cervical cancer screening in low resource settings using visual inspection with acetic acid. Journal of Midwifery \& Women's Health. 2004;49(4):329-37.

5. Gordis L. Epidemiology. 3rd. Philadelphia, PA: WB Saunders; 2004.

6. Schulz KF, Altman DG, Moher D. CONSORT 2010 statement: updated guidelines for reporting parallel group randomised trials. BMC Med. 2010;8(1):18.

7. Singh E, Seth S, Rani V, Srivastava DK. Awareness of cervical cancer screening among nursing staff in a 
tertiary institution of rural India. Journal of gynecologic oncology. 2012;23(3):141-6.

8. Lehrer K. Theory of knowledge. 1990, Routledge.

9. Mutyaba T, Mmiro FA, Weiderpass E. Knowledge, attitudes and practices on cervical cancer screening among the medical workers of Mulago Hospital, Uganda. BMC medical education. 2006;6(1):13.

10. Tchounga BK, Jaquet A, Coffie PA, Horo A, Sauvaget $C$, Adoubi I, et al. Cervical cancer prevention in reproductive health services: knowledge, attitudes and practices of midwives in Cote d'Ivoire, West Africa. BMC health services research. 2014;14(1):165.

11. Epstein RM, Hundert EM. Defining and assessing professional competence. Jama. 2002;287(2):22635.

12. Fort AL, Voltero L. Factors affecting the performance of maternal health care providers in Armenia. Human resources for health. 2004;2(8):1-11.

13. Jia $Y$, Li S, Yang R, Zhou H, Xiang Q, Hu T, et al. Knowledge about Cervical Cancer and Barriers of Screening Program among Women in Wufeng County, a High-Incidence Region of Cervical Cancer in China. PLoS One. 2013;8(7):e67005.

14. Willetts $L$, Leff J. Improving the knowledge and skills of psychiatric nurses: efficacy of a staff training programme. Journal of advanced nursing. 2003;42(3):237-43.

15. Harahap M. Ekspresi Vascular Endothelial Growth Factor Pada Karsinoma Nasofaring. 2009.

16. Urasa M, Darj E. Knowledge of cervical cancer and screening practices of nurses at a regional hospital in Tanzania. African health sciences. 2011;11(1).

17. Kottke T, Trapp M. Implementing nurse-based systems to provide American Indian women with breast and cervical cancer screening. Mayo Clin Proc. 1998;73(9):815-23.
18. Diknas RI. Undang-undang Sisdiknas, Departemen Pendidikan Nasional. Jakarta: Depdiknas; 2002.

19. Fauziah RM, Wirawan JP, Lorianto R, Utari AP, Cahyanur R, Budiningsih S. Early Detection of Cervical Cancer in Primary Health Care in Five Areas of Jakarta. Journal of the Indonesian Medical Association. 2012;61(11).

20. Carlough M, McCall M. Skilled birth attendance: What does it mean and how can it be measured? A clinical skills assessment of maternal and child health workers in Nepal. International Journal of Gynecology \& Obstetrics. 2005;89(2):200-8.

21. Gammon J, Gould D. Universal precautions: A review of knowledge,compliance and strategies to improve practice. Journal of Research in Nursing. 2005;10 (3):529-47.

22. Türkistanlý E, Sogukpýnar N, Saydam BK, Aydemir G. Cervical cancer prevention and early detection; the role of nurse and midwives. Asian Pacific J Cancer Prev. 2003;4(1):39-44.

23. Muchlas M. Perilaku Organisasi. Yogyakarta: Gadjah Mada University Press; 2005.

24. Hanafi I, Ocviyanti D. Efektivitas pemeriksaan inspeksi visual dengan asamasetat oleh bidan sebagai upaya mendeteksi lesi pra-kanker serviks. Indones J ObstetGynecol. 2003;27(1):59-66.

25. Sismiarti. Evaluasi Kualitas Pemeriksaan Skrining IVA (inspeksi Visual Asam Asetat) Bagi Petugas yang Telah Mendapatkan Pelatihan Khusus dan yang Belum di Puskesmas Kota Kediri Tahun 2010. Yogyakarta: Program Pascasarjana Ilmu Kesehatan Masyarakat, Fakultas Kedokteran, Universitas Gadjah Mada; 2011.

26. Robbins SP. Organizational Behavior. Prentice - Hall: Upper Saddle River, NJ; 2001. 